\title{
Development of Ethylene-synthesizing Capacity in Preclimacteric Apples: Interaction between Abscisic Acid and Ethylene
}

\author{
I. Lara \\ Universitat de Lleida-Institut de Recerca i Tecnologia Agroalimentàries (UdL-IRTA), Alcalde Rovira \\ Roure 177, 25198 Lleida, Spain \\ M. Vendrell ${ }^{1}$ \\ Centre d'Investigació i Desenvolupament-Consejo Superior de Investigaciones Científicas (CID-CSIC), \\ Jorge Girona 18-26, 08034 Barcelona, Spain
}

\begin{abstract}
AdDitional INDEX wORDs. 1-aminocyclopropane-1-carboxylic acid, ACC oxidase, ACC synthase, Malus sylvestris var. domestica, ripening

Abstract. ABA and ethylene treatments were applied to preclimacteric 'Granny Smith' apples [Malus sylvestris (L.) Mill. var. domestica (Borkh.) Mansf.] harvested at three different maturity stages. Ethylene production rates, ethyleneforming capacity (EFC), free and conjugated ACC contents, presence of ACC oxidase (ACO) and ripening-related ACC synthase (ACS) proteins, and endogenous ABA levels were monitored at harvest and during 3 weeks thereafter. ABA treatment resulted in a specific accumulation of ACO protein and of ACS-related polypeptides in fruit collected $\approx 2$ months before commercial harvest, whereas the same tissues showed no response to exogenous ethylene. In contrast, fruit harvested 1 month later proved more sensitive to ethylene but not to $\mathrm{ABA}$, in accordance with evolution of endogenous ABA levels, which were highest at this maturity stage and were enhanced in response to exogenous ethylene. A possible role for $\mathrm{ABA}$ as an inductor of the competency to ripen is discussed. Chemical names used: abscisic acid (ABA); 1aminocyclopropane-1-carboxylic acid (ACC).
\end{abstract}

Global knowledge of the processes leading to fruit maturation and ripening still lacks an understanding of the factors controlling ethylene biosynthesis, the plant hormone playing a key role in ripening of apples (Malus sylvestris var. domestica) as well as other climacteric fruit. Indeed, although the rise in ethylene synthesis associated with the climacteric appears to be the main regulatory event in ripening, other regulatory events precede and follow this rise. The large increase in ethylene biosynthesis at the onset of ripening, characteristic for climacteric fruit, is believed to mediate the expression of the genes involved in ripening. Accumulation of de novo-synthesized ripening-related proteins and mRNAs has been reported in apple (Lay-Yee et al., 1990; Lu et al., 1992), banana (Musa acuminata Colla) (DomínguezPuigjaner et al., 1992), tomato (Lycopersicon esculentum Mill.) (Biggs et al., 1986; Davies and Grierson, 1989; Lincoln et al., 1987; Olson et al., 1991; Smith et al., 1986), avocado (Persea americana Mill.) (Bozak et al., 1990; Tucker and Laties, 1984) and peach [Prunus persica (L.) Batsch (Peach Group)] (Callahan et al., 1989).

Although ACC synthase (ACS) is recognized to be a major regulatory step in ethylene biosynthesis (Yang and Dong, 1993),

Received for publication 28 Apr. 1999. Accepted for publication 7 Mar. 2000 This work is a portion of research submitted by I. Lara in partial fulfillment of the requirements for the $\mathrm{PhD}$ degree. The authors are grateful to $\mathrm{D}$. Dilley, Michigan State University, East Lansing, for the generous gift of apple ACO antibody, A. Latché, Ecole Nationale Supérieure Agronomique de Toulouse, France, for the generous present of antibodies against recombinant ACO, and S.F. Yang, Institute of Botany, Academia Sinica, Taiwan, for kindly providing apple ripening-related ACS antibody. J. Voltas is also acknowledged for statistical assistance. I. Lara was recipient of a grant from Instituto Nacional de Investigación y Tecnología Agroalimentaria (INIA), Madrid, Spain. This work was supported by project INIA-9672, financed by INIA. The cost of publishing this paper was defrayed in part by the payment of page charges. Under postal regulations, this paper therefore must be hereby marked advertisement solely to indicate this fact.

'Corresponding author: mvmagr@cid.csic.es. both the conversion of S-adenosyl-L-methionine (SAM) to ACC and the oxidation of ACC to ethylene are restricted in preclimacteric apple tissues. The low levels of ACC in preclimacteric immature 'Granny Smith' fruit, along with the observation that ACC oxidase (ACO) protein was undetectable throughout the preclimacteric period (Lara and Vendrell, 2000), suggest both that availability of ACC is a limiting factor regulating ethylene production and that preclimacteric tissue lacks the capability for the conversion of ACC to ethylene.

There have been several reports that treatment of climacteric fruit with ethylene induces ripening (Bufler, 1986; Burg and Burg, 1962; Domínguez and Vendrell, 1994; Inaba and Nakamura, 1986, 1988; Liu et al., 1985a), and ethylene is capable of regulating the activity of the ethylene-forming enzyme (EFE, an older synonym for ACO) (Hoffman and Yang, 1984), ACC synthase (Bufler, 1984) and malonyl-ACC transferase (Liu et al., 1985b). However, the changing sensitivity of fruit tissues to endogenous ethylene has been recognized as being more important than a simple increase in ethylene production in governing the timing of the onset of ripening in climacteric fruit. This sensitivity is now known to increase with advancing age of the fruit, and to be affected by many factors, including the balance of endogenous plant growth regulators (Reid, 1985).

ABA and ethylene have an accelerating effect on senescence, abscission, and to mediate stress responses. They therefore seem to interact in several plant physiological processes. Exogenous ABA has been reported to induce ethylene biosynthesis in ripening fruit, including apples (Brady, 1987; Riov et al., 1990; Vendrell and Buesa, 1989), as well as in other plant tissues (Gómez Cadenas et al., 1996; Tari and Nagy, 1996). Furthermore, endogenous ABA increases during maturation of several fruit (Kondo et al., 1991; Kondo and Gemma, 1993; Martínez Madrid et al., 1996; Uthaibutra and Gemma, 1991), including 'Granny Smith' apples (Lara and Vendrell, 2000). Therefore, the question 
arises whether ABA acts through a regulation of endogenous ethylene production or action, perhaps by inducing an increase in tissue sensitivity to ethylene. It may also be possible that some aspects of both ethylene-mediated and ethylene-independent regulation are effected by $\mathrm{ABA}$.

In the present paper, the effects of $\mathrm{ABA}$ and ethylene treatments on the development of ethylene-synthesizing capacity in pulp and peel tissues of preclimacteric 'Granny Smith' apples are reported. Both tissues were used for this study, based on previous reports suggesting different regulatory mechanisms operate in different plant tissues (Lara and Vendrell, 2000; Moya-León and John, 1995), and of increasing evidence indicating that expression of ethylene-biosynthetic genes is tissue specific (Lelièvre et al., 1997; Nakatsuka et al., 1998; Peck et al., 1998). Ethylene production, ethylene-forming capacity (EFC), ACC content, and $\mathrm{ACO}$ and ACS protein accumulation at three different maturity stages were monitored, with the aim of assessing tissue sensitivity to both growth regulators as affected by maturity stage. Analysis of endogenous ABA contents in both nontreated and ethylenetreated fruit were carried out to test whether ethylene might enhance ethylene production through a change in endogenous ABA levels. The purpose of this work was to investigate whether ABA plays a role in the induction and regulation of the ripening process of 'Granny Smith' apples.

\section{Materials and Methods}

Plant material and hormonal treatments. Preclimacteric 'Granny Smith' apples from Vallfonda, Lleida (Spain) were collected at three different maturity stages: $\mathrm{H}_{2}, \mathrm{H}_{1}$, and $\mathrm{H}_{\mathrm{C}}(2$ months before commercial harvest, 1 month before commercial harvest, and at commercial harvest, respectively), and selected for uniformity of size and absence of defects. Commercial harvest took place at $\approx 200 \mathrm{~d}$ after full bloom. Quality parameters at this stage averaged $64.4 \mathrm{~N}$ firmness, soluble solids content of $11 \mathrm{~g} / 100$ $\mathrm{g}$ fresh weight $(\mathrm{FW})$, and malic acid content of $63.6 \mathrm{mmol} \cdot \mathrm{L}^{-1}$. Three samples of 30 fruit were taken from a row of trees at each harvesting date. Immediately after harvest, fruit either remained nontreated or were ABA or ethylene treated as described below, and thereafter kept at $20^{\circ} \mathrm{C}$ during 3 weeks. Both pulp (cortex) and peel tissue samples were taken for analysis immediately after harvest and once per week, frozen in liquid nitrogen, lyophilized, reduced to powder and kept at $-80{ }^{\circ} \mathrm{C}$ until processing. ABA treatment was performed by a $1-\mathrm{mL}$ injection into the core cavity of $1 \mathrm{mmol} \cdot \mathrm{L}^{-1}( \pm)$-cis, trans-ABA (Sigma, St. Louis, Mo.), as described previously (Vendrell and Buesa, 1989). The injection was considered successful when no mechanical opposition was observed. Fruit treated in the same way with ultrapure water (MilliQ; Millipore Corp., Bedford, Mass.) served as controls. For ethylene treatment, the procedure was as reported elsewhere (Domínguez and Vendrell, 1994). Briefly, fruit were placed in closed 2-L jars, with a septum through which ethylene in nitrogen $(5 \%, \mathrm{v} / \mathrm{v})$ was injected to create a concentration of $250 \mu \mathrm{L} \cdot \mathrm{L}^{-1}$, which was verified by gas chromatography as described below. After treatment for $48 \mathrm{~h}$, samples were ventilated to eliminate the ethylene.

ETHYLENE PRODUCTION. Four apples per treatment were placed individually in 350-mL containers continuously aerated with $\approx 1$ $\mathrm{L} \cdot \mathrm{h}^{-1}$ of humidified air. For ethylene analysis, $2-\mathrm{mL}$ gas samples were taken periodically from the effluent air and injected into a gas chromatograph (Model 5890, Hewlett Packard Co., Palo Alto, Calif.) equipped with an activated alumina column $(2 \mathrm{~m} \times$
$4 \mathrm{~mm}$ i.d., Supelco Inc., Bellefonte, Pa.) and a flame ionization detector. Ethylene production was expressed as $\mu \mathrm{L} \cdot \mathrm{kg}^{-1} \cdot \mathrm{h}^{-1}$.

ETHYLENE-FORMING CAPACITY. EFC of pulp and peel tissues was determined in vivo as described previously (Lara and Vendrell, 1998b) by measuring the conversion of exogenous ACC to ethylene on $1 \mathrm{~g}$ (FW) samples from pulp or peel tissues from four apples. Cylinders of pulp tissue were removed radially with an 8$\mathrm{mm}$ (i.d.) steel cork borer and cut into uniform discs $1 \mathrm{~mm}$ thick. Thin strips of peel were removed carefully with a fruit peeler. Samples were placed in a $20-\mathrm{mL}$ vial containing $3 \mathrm{~mL}$ of incubation medium (mannitol at $0.4 \mathrm{~mol} \cdot \mathrm{L}^{-1}, \mathrm{MES}-\mathrm{KOH}$ at $50 \mathrm{mmol} \cdot \mathrm{L}^{-1}, \mathrm{pH}$ 7.0 for pulp; mannitol at $0.4 \mathrm{~mol} \cdot \mathrm{L}^{-1}, \mathrm{MES}-\mathrm{KOH}$ at $10 \mathrm{mmol} \cdot \mathrm{L}^{-1}$, $\mathrm{pH} 6.1$ for peel) in the presence of $\mathrm{ACC}$ at $5 \mathrm{mmol} \cdot \mathrm{L}^{-1}$ and cycloheximide at $0.1 \mathrm{mmol} \cdot \mathrm{L}^{-1}$. Sealed flasks were then incubated at $20^{\circ} \mathrm{C}$ for $3 \mathrm{~h}$, and gas samples were taken for ethylene analysis by gas chromatography. Ethylene production was expressed as nmol $\cdot \mathrm{g}^{-1} \cdot \mathrm{h}^{-1}$.

ACC AND MALONYL-ACC (MACC) CONCENTRATions. About 0.15 $\mathrm{g}$ (pulp) or $0.22 \mathrm{~g}$ (peel) of lyophilized tissue, equivalent to $1 \mathrm{~g}$ (FW), was taken to analyze both ACC and MACC contents. Samples were extracted under reflux for $15 \mathrm{~min}$ with ethanol at $13.5 \mathrm{~mol} \cdot \mathrm{L}^{-1}(80 \%, \mathrm{v} / \mathrm{v})$, which was removed under vacuum at 40 ${ }^{\circ} \mathrm{C}$. ACC was measured directly on the aqueous extract according to the method of Lizada and Yang (1979). Total ACC content was determined from the aqueous extract, hydrolyzed previously with $\mathrm{HCl}$ at $7.2 \mathrm{~mol} \cdot \mathrm{L}^{-1}$ at $100{ }^{\circ} \mathrm{C}$ for $3 \mathrm{~h}$, following the method described by Hoffman et al. (1982). MACC was taken as the difference between total and free ACC contents. ACC concentrations were expressed as $\mathrm{nmol} \cdot \mathrm{g}^{-1}(\mathrm{FW})$.

Endogenous ABA Content. ABA content was determined according to the method described by Carrasquer et al. (1990), with slight modifications. Briefly, samples $(500 \mathrm{mg})$ of homogenized lyophilized tissue were extracted for $36 \mathrm{~h}$ in the dark on a shaker at $4{ }^{\circ} \mathrm{C}$ with methanol at $24.7 \mathrm{~mol} \cdot \mathrm{L}^{-1}$, phosphoric acid at $6.8 \mathrm{mmol} \cdot \mathrm{L}^{-1}(80: 20, \mathrm{v} / \mathrm{v})$, and 2,6-di-tert-butyl-4-methylphenol (BHT) at $100 \mathrm{mg} \cdot \mathrm{L}^{-1}$ as an antioxidant. The filtrate was adjusted to $\mathrm{pH} 8.5$, and methanol removed under vacuum at $35^{\circ} \mathrm{C}$. The aqueous phase was prepurified by loading onto a Sep-Pak $\mathrm{C}_{18}$ cartridge (Waters Corp., Milford, Mass.). The eluted fraction was lyophilized and stored at $-20{ }^{\circ} \mathrm{C}$ until injection into a highperformance liquid chromatography (HPLC) system (Applied Biosystems, Inc., Foster City, Calif.) for ABA separation and further quantification. The fraction containing the ABA peak was collected after detection, lyophilized, and stored until mass spectrometric analysis for peak confirmation. ABA concentrations were expressed as nmol. $\mathrm{g}^{-1}$ dry weight (DW).

TOTAL PROTEIN EXTRACTION, SODIUM DODECYL SULFATE-POLYACRYLAMIDE GEL ELECTROPHORESIS (SDS-PAGE), AND IMMUNOBLOTTING. Total soluble proteins of pulp and peel tissues were extracted according to Domínguez-Puigjaner et al. (1992), with slight modifications. Homogenized lyophilized tissue $(150 \mathrm{mg})$ was extracted with buffer (Tris- $\mathrm{HCl}$ at $0.25 \mathrm{~mol} \cdot \mathrm{L}^{-1}, \mathrm{pH} 8.4$, glycine at $0.2 \mathrm{~mol} \cdot \mathrm{L}^{-1}, \mathrm{SDS}$ at $0.014 \mathrm{~mol} \cdot \mathrm{L}^{-1}, 2$-mercaptoethanol at $\left.1.4 \mathrm{~mol} \cdot \mathrm{L}^{-1}\right)$. After centrifugation $\left(12,000 \mathrm{~g}_{\mathrm{n}}\right.$ for $15 \mathrm{~min}$ at $\left.4{ }^{\circ} \mathrm{C}\right)$, proteins in the supernatant were precipitated with $15 \%(\mathrm{v} / \mathrm{v})$ trichloroacetic acid (TCA) and washed in methanol/ ammonium acetate at $0.1 \mathrm{~mol} \cdot \mathrm{L}^{-1}$, vacuum dried, and stored at $-80^{\circ} \mathrm{C}$ until electrophoretical separation. For SDS-PAGE, the pellet was dissolved in $50 \mu \mathrm{L}$ sample buffer (Tris- $\mathrm{HCl}$ at $60 \mathrm{mmol} \cdot \mathrm{L}^{-1}, \mathrm{pH}$ 6.8 , glycerol at $1.36 \mathrm{~mol} \cdot \mathrm{L}^{-1}$, SDS at $0.07 \mathrm{~mol} \cdot \mathrm{L}^{-1}$, and 2mercaptoethanol at $\left.0.7 \mathrm{~mol} \cdot \mathrm{L}^{-1}\right)$. Aliquots $(20 \mu \mathrm{L})$ were loaded in each lane for SDS-PAGE and run on a $10 \%(\mathrm{w} / \mathrm{v})$ gel using a 

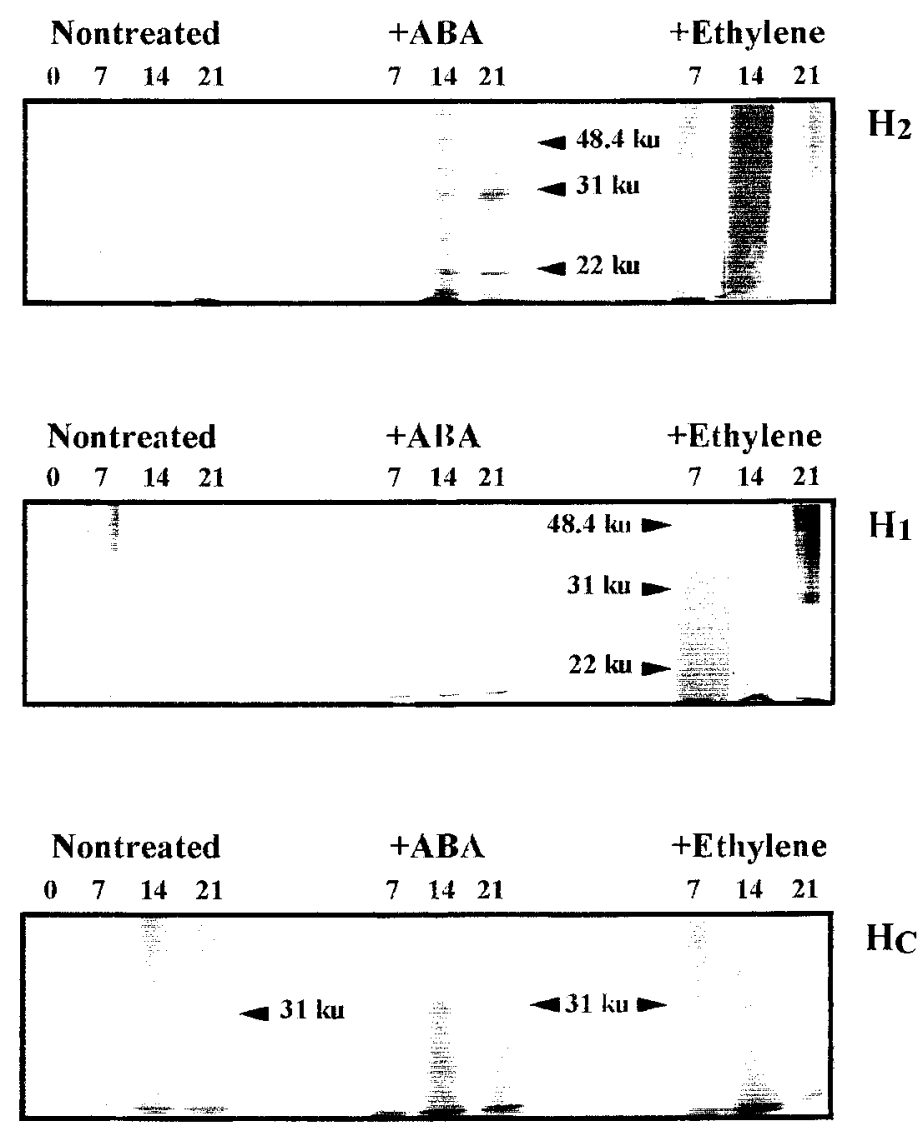

Fig. 1. SDS-PAGE of polypeptides obtained after ACC synthase immunoprecipitation from extracts of pulp of 'Granny Smith' apples collected 2 months before commercial harvest $\left(\mathrm{H}_{2}\right), 1$ month before commercial harvest $\left(\mathrm{H}_{1}\right)$, and at commercial harvest $\left(\mathrm{H}_{\mathrm{C}}\right)$. Measurements were performed $0,7,14$, or $21 \mathrm{~d}$ after collection. Black arrows indicate ACS-related polypeptides. Gels were silver stained.

Mini-Protean II apparatus (Bio-Rad Laboratories, Hercules, Calif.) according to the manufacturer's instructions. Prestained molecular weight markers (Bio-Rad) were used. Protein concentrations were measured by the Bradford (1976) method, with modifications (Bio-Rad Protein Assay), using bovine serum albumin (BSA) as a standard. Separated polypeptides were blotted onto a polyvinylidene fluoride (PVDF) membrane (ImmobilonP; Millipore) using a semidry electrophoretic transfer cell (Bio$\mathrm{Rad}$ ) according to the recommendations of the manufacturer, and immunodetection was performed using routine procedures (Ausubel et al., 1997). Antibodies raised against ACC oxidase (a gift from D. Dilley and from A. Latché) were used to monitor accumulation of ACO protein in our samples. Blots were developed with ECL Western Blotting Detection Kit (Amersham Life Science Ltd., Buckinghamshire, United Kingdom), and signals were quantified using a Lumi Analyst 2.0 program (Boehringer Mannheim GmbH, Mannheim, Germany).

ACS PROTEIN IMMUNOPRECIPITATION. Immunoprecipitation assays were undertaken to assess the presence or absence of ripening-related ACC synthase (ACS) in our samples, according to published protocols (Ausubel et al., 1997). In total, $150 \mathrm{mg}$ of lyophilized homogenized tissue was incubated in $1 \mathrm{~mL}$ lysis buffer $(0.5 \%$ (v/v) Triton X-100, phenylmethylsulfonyl fluoride at $1 \mathrm{mmol} \cdot \mathrm{L}^{-1}$, iodoacetamide at $5 \mathrm{mmol} \cdot \mathrm{L}^{-1}$, and 0.2 trypsin inhibitor units (TIU) aprotininin/mL in Tris-Saline-Azide (TSA) solution) for $1 \mathrm{~h}$ at $4{ }^{\circ} \mathrm{C}$. After centrifugation, the supernatant was precleared with a 1:1 slurry of cyanogen bromide $(\mathrm{CNBr})$ activated Sepharose 4B (Pharmacia Biotech, Uppsala, Sweden) in TSA solution (Tris- $\mathrm{HCl}$ at $0.01 \mathrm{~mol} \cdot \mathrm{L}^{-1}, \mathrm{pH} 8.0, \mathrm{NaCl}$ at 0.14 $\mathrm{mol} \cdot \mathrm{L}^{-1}$, and $\mathrm{NaN}_{3}$ at $3.8 \mathrm{mmol} \cdot \mathrm{L}^{-1}$ ) at $4{ }^{\circ} \mathrm{C}$ for $1 \mathrm{~h}$ to precipitate nonspecifically bound materials. The nonprecipitating fraction was then incubated for $1 \mathrm{~h}$ at $4{ }^{\circ} \mathrm{C}$, with slow rotation, with an appropriate dilution of monoclonal antibody raised against ripening-related apple ACS (a gift from S.F. Yang) previously coupled to a CNBr-activated Sepharose slurry in TSA. The antigenantibody-Sepharose complex was then pelleted by centrifugation $\left(12,000 \mathrm{~g}_{n}\right.$ for $15 \mathrm{~min}$ at $\left.4{ }^{\circ} \mathrm{C}\right)$, and the supernatant was discarded. The pellet was washed twice with $0.1 \%$ Triton X-100 in TSA, then with TSA and finally with Tris- $\mathrm{HCl}$ at $0.05 \mathrm{~mol} \cdot \mathrm{L}^{-1}, \mathrm{pH}$ 6.8. After this washing procedure, the sample was resuspended in $30 \mu \mathrm{L}$ SDS-PAGE sample buffer, heated at $90{ }^{\circ} \mathrm{C}$ for $5 \mathrm{~min}$, centrifuged $5 \mathrm{~s}$ to pellet Sepharose and loaded for analysis onto a $12 \%$ (w/v) gel in a Mini-Protean II apparatus (Bio-Rad), according to the manufacturer's instructions. Standard molecular weight markers (Sigma) were used. Separated polypeptides were fixed and silver stained using a commercially available kit (Sigma) according to the manufacturer's protocol.

Statistical analysis. Data were subjected to analysis of variance procedures. For ethylene production rate, treatment was C used as a main factor, with time-course evolution nested to each treatment. For ABA, EFC, and free- and malonyl-ACC levels, treatment and time-course evolution were used as main factors. Unless otherwise mentioned, only results significant at $P<0.05$ are discussed. LSD values $(P=0.05)$ were calculated, and included in the figures to facilitate comparison between treatment means.

\section{Results and Discussion}

ACS PROTEIN IMMUNOPRECIPITATION. In immunoprecipitation assays, polypeptides were found in some of the samples of $\approx 48.4$ $\mathrm{ku}$ (Fig. 1). This is in accordance with Dong et al. (1991), who reported apple ripening-related ACS to be a polypeptide of $48 \mathrm{ku}$ molecular weight. In addition, two smaller polypeptides, of $\approx 31$ and $22 \mathrm{ku}$, were also found on SDS-PAGE gels following immunoprecipitation. Because these polypeptides were isolated from crude extracts using a Sepharose slurry coupled to a specific antibody raised against ripening-related apple ACS, and the extract had been precleared previously in order to precipitate any materials nonspecifically binding to Sepharose, we consider these to be ACS-related polypeptides. Taking into account that ACC synthase is known to exist in very low concentrations and to be unstable (Yang and Dong, 1993), degradation might have taken place during the lysis, preclearing or immunoprecipitation steps. Dong et al. (1991) also reported on the appearance of a 38 ku polypeptide on immunoblots following ACS immunoprecipitation. Different molecular weights might represent different degradation degrees of the protein fragment containing the epitope.

These polypeptides appeared differentially and consistently with the rest of results in response to the different treatments applied. Most interestingly, they were clearly induced in pulp of $\mathrm{H}_{2}$ fruit in response to ABA treatment, whereas at the $\mathrm{H}_{1}$ stage they could be detected only in ethylene-treated fruit. $\mathrm{In}_{\mathrm{C}}$ fruit, only the $31 \mathrm{ku}$ polypeptide was detectable, and both exogenous ABA and ethylene advanced its appearance. Only the smaller polypeptides were detected in the peel of $\mathrm{H}_{2}$ and $\mathrm{H}_{\mathrm{C}}$ fruit (results not presented). In contrast, ACS, identified as the $48.4 \mathrm{ku}$ polypeptide, was found in the peel at the $\mathrm{H}_{1}$ stage, and its appearance was 


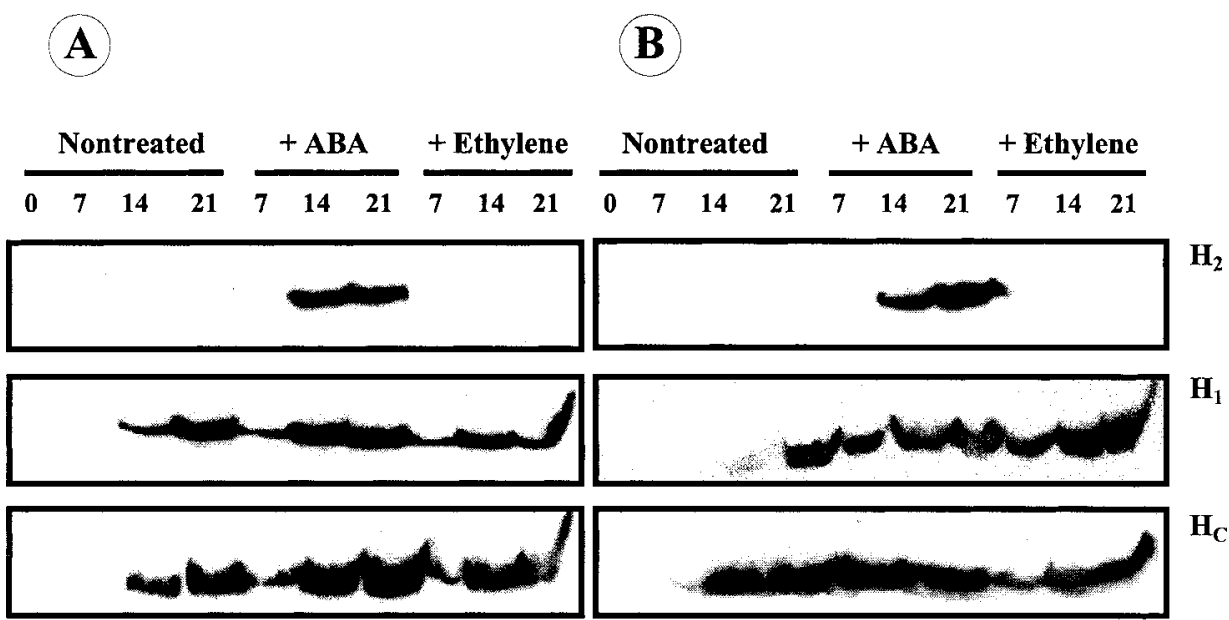

advanced in ethylene-treated when compared with nontreated fruit, in accordance with the observations for the pulp tissue.

EXOGENOUS ABA DIFFERENTIALLY INDUCED ETHYLENE-FORMING CAPACITY AT DIFFERENT MATURITY STAGES. ACO was

$\mathbf{H}_{2}$ not detectable at harvest (Fig. 2) at any of the three stages. This is in accordance with previous results (Lara and Vendrell, 2000) showing ACO protein to be undetectable and EFC to be very low throughout the maturation period of "Granny Smith' apples, thus indicating ethylene $\mathbf{H}_{C}$ production by preclimacteric fruit may be limited at least in part by a reduced ability to convert ACC to ethylene. Nontreated $\mathrm{H}_{1}$ and $\mathrm{H}_{\mathrm{C}}$ apples showed a higher and

Fig. 2. Immunoblot of ACC oxidase protein in (A) peel and (B) pulp of 'Granny Smith' apples collected 2 months before commercial harvest $\left(\mathrm{H}_{2}\right), 1$ month before commercial harvest $\left(\mathrm{H}_{1}\right)$, and at commercial harvest $\left(\mathrm{H}_{\mathrm{C}}\right)$. Measurements were performed $0,7,14$, or $21 \mathrm{~d}$ after collection. Blots were developed with the chemiluminiscent ECL system.

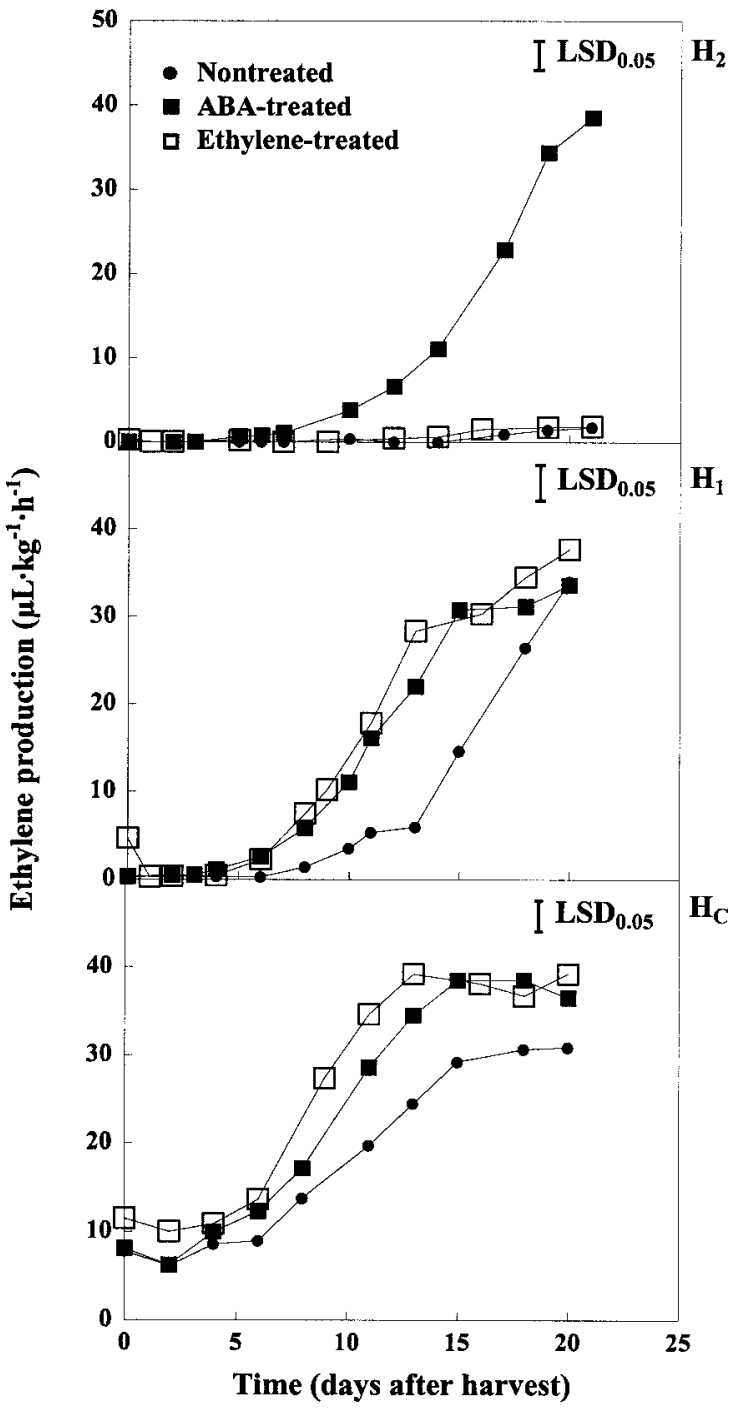

Fig. 3. Ethylene production rates of 'Granny Smith' apples collected 2 months before commercial harvest $\left(\mathrm{H}_{2}\right), 1$ month before commercial harvest $\left(\mathrm{H}_{1}\right)$, and at commercial harvest $\left(\mathrm{H}_{\mathrm{C}}\right)$. Values represent means of four replications. earlier rise in ethylene production (Fig. 3), compared with more immature apples, reflecting a more advanced maturity stage. Increases in ethylene production were paralleled by rises in EFC (Fig. 4) and ACO protein (Fig. 2). Evolution of ACC (Fig. 5) and MACC contents (data not presented) suggests that ACS was present and active in these more mature tissues, as was observed in the peel at the $\mathrm{H}_{1}$ stage (data not presented), although in pulp tissue, immunoprecipitation assays could barely detect ACSrelated polypeptides. The fact that ACS is present in $\mathrm{H}_{1}$ and $\mathrm{H}_{\mathrm{C}}$ tissues is in accordance with our previous results, showing ACC to accumulate sharply in both peel and pulp tissues of 'Granny Smith' apples from $\approx 1$ month before commercial harvest (Lara and Vendrell, 2000).

Exogenous ABA caused induction of ethylene biosynthesis in both pulp and peel of very immature $\left(\mathrm{H}_{2}\right)$ fruit, as indicated by the appearance of ACO protein (Fig. 2), accompanied by an increase in EFC (Fig. 4) and ethylene production (Fig. 3). Because waterinjected fruit (data not presented) displayed no significant increase in ethylene production, compared with nontreated fruit, enhancement of ethylene biosynthesis in ABA-treated fruit should not be attributed to a wounding effect of the treatment method, but rather to applied ABA itself. Moreover, results of ACO immunoblots suggest that applied ABA could have a different effect on different tissues. Whereas an increase in ACO protein was found between 14 and $21 \mathrm{~d}$ after harvest (DAH) in the pulp, which was complemented by a moderate increment in EFC, no large differences were found in ACO protein levels in the peel, although a sharp increase in EFC was measured. This seems to suggest that exogenous $\mathrm{ABA}$ might have an effect on the quantity of ACO in the pulp, whereas in the peel this effect would be exerted rather on enzymatic activity. In addition, higher ACC levels in the pulp tissue may be reflecting increased ACS activity, confirmed by results of immunoprecipitation assays which show preferential accumulation of ACS-related polypeptides in response to applied ABA (Fig. 1).

In contrast, exogenous ABA had no effect on ethylene production of $\mathrm{H}_{1}$ or $\mathrm{H}_{\mathrm{C}}$ fruit, which, although higher compared with nontreated fruit, was indistinguishable from that of water-injected fruit (data not presented). Enhancement of ethylene production may be attributed to the wounding effect of the injection treatment rather than to a real effect of applied ABA, and this effect reflects a more advanced maturity stage. Nevertheless, the noticeable accumulation of MACC found in both peel and pulp of ABA-treated $\mathrm{H}_{1}$ fruit $21 \mathrm{DAH}$ (data not presented) probably indicates some ABA-induced activation of malonyl transferase 

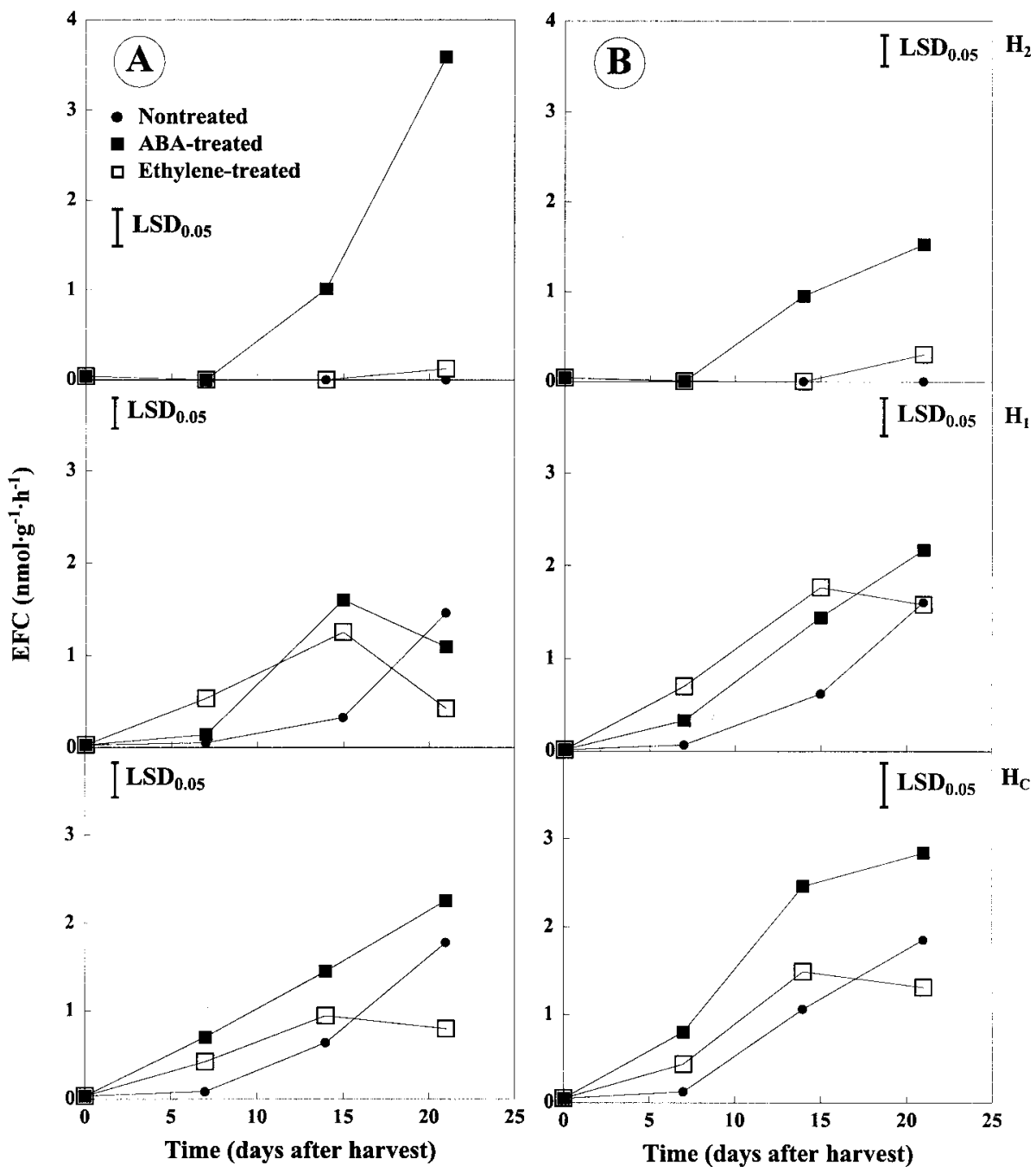

ENE-SYNTHESIZING CAPACITY. Ripening of apples after harvest exhibits a lag period characterized by low, steady respiration rates and low levels of ethylene production, followed by a sharp autocatalytic increase in ethylene production accompanied by a peak of respiratory activity along with changes in color, aroma, and texture (Knee, 1993). This lag period has a variable duration, depending on fruit maturity. Two systems of ethylene production have been suggested to operate during maturation and ripening of climacteric fruit (McMurchie et al., 1972). A hypothetical System 1 producing a low basal rate of ethylene is followed by System 2 ethylene, which is responsible for the characteristic rise in ethylene production. It is considered that the lag period involves a progressive increase in responsiveness to ethylene to the point where the endogenous ethylene level triggers the climacteric. Ethylene itself is involved in implementing the change in sensitivity, although it cannot be wholly responsible. Our results showed that endogenous ABA levels in 'Granny Smith' apples increased with advancing maturity stage (Fig. 6), thus providing the possibility of a regulatory role for $\mathrm{ABA}$ in triggering the climacteric response. These data are also in accordance with our observation that exogenous ABA dramatically induced ethylene biosynthesis in very immature 'Granny Smith' apples whereas the same treatment failed to enhance ethylene biosynthesis in more mature fruit. Higher

Fig. 4. Ethylene-forming capacity (EFC) in (A) peel and (B) pulp of 'Granny Smith' apples collected 2 months before commercial harvest $\left(\mathrm{H}_{2}\right), 1$ month before commercial harvest $\left(\mathrm{H}_{1}\right)$, and at commercial harvest $\left(\mathrm{H}_{\mathrm{C}}\right)$. Values represent means of four replications.

activity in these fruit, even though no detectable ACS-related polypeptides were found. Because applied ABA did not induce an enhancement of EFC although ACO protein accumulation was advanced by the treatment (Fig. 2), it can be inferred that either the enzyme was not active or that no ACC was available for its action. Negligible ACC levels were found both in peel and in pulp after $7 \mathrm{DAH}$ (when ACO protein was already present in ABA-treated fruit), and it has been reported previously that in preclimacteric tissues compartmentalization of ACC may also be an efficient mechanism preventing ripening of 'Passe-Crassane' pear (Pyrus communis L.) fruit (Lara and Vendrell, 1998a). Malonylation of ACC would be a mechanism helping to remove ACC from ACO action.

No ABA-induced ACC or MACC accumulation took place in $\mathrm{H}_{\mathrm{C}}$ fruit (Fig. 5), although exogenous ABA enhanced EFC (Fig. 4 ), and advanced accumulation of ACO protein in both peel and pulp (Fig. 2) and of an ACS-related polypeptide in the pulp (Fig. 1 ), suggesting that ABA could act as a signal switching from maturation to climacteric in this preclimacteric, ready-to-ripen mature system.

ETHYLENE AND ABA INTERACT IN THE DEVELOPMENT OF ETHYL- endogenous ABA levels found in more mature tissues could be saturating, thus rendering ineffective exogenous $\mathrm{ABA}$ treatment. Interestingly, the highest levels measured in the pulp tissue were found in $\mathrm{H}_{1}$ fruit and not in $\mathrm{H}_{\mathrm{C}}$ apples, thereby providing an indication that a transient increase in endogenous ABA may be a preliminary step in the climacteric process. It is also noticeable that only at the $\mathrm{H}_{1}$ stage did exogenous ethylene induce an increase in ABA content (Fig. 6B), suggesting that at this developmental stage ethylene could be up-regulating ABA synthesis. In contrast, ethylene inhibited or did not enhance $\mathrm{ABA}$ accumulation in $\mathrm{H}_{\mathrm{C}}$ and $\mathrm{H}_{2}$ fruit, indicating that up-regulation of $\mathrm{ABA}$ biosynthesis and/or perception pathways by ethylene is a transient event during the preclimacteric period of 'Granny Smith' apples. Ethylene-treated $\mathrm{H}_{\mathrm{C}}$ fruit showed lower endogenous $\mathrm{ABA}$ content, compared with nontreated apples (Fig. 6). Nevertheless, ACC synthase activity was higher in treated fruit, as shown by higher ethylene production rates in ethylene-treated compared with nontreated fruit despite similar EFC and ACC content. This observation might have different explanations: either once ACC synthase is induced the process becomes irreversible and ABA independent, or $\mathrm{ABA}$ is being catabolized during its action on ACS.

Exogenous ethylene did not induce ethylene biosynthesis in $\mathrm{H}_{2}$ fruit, as indicated by ethylene production rates (Fig. 3), EFC (Fig. 4), presence of ACO (Fig. 2) or ACC contents (Fig. 5), 

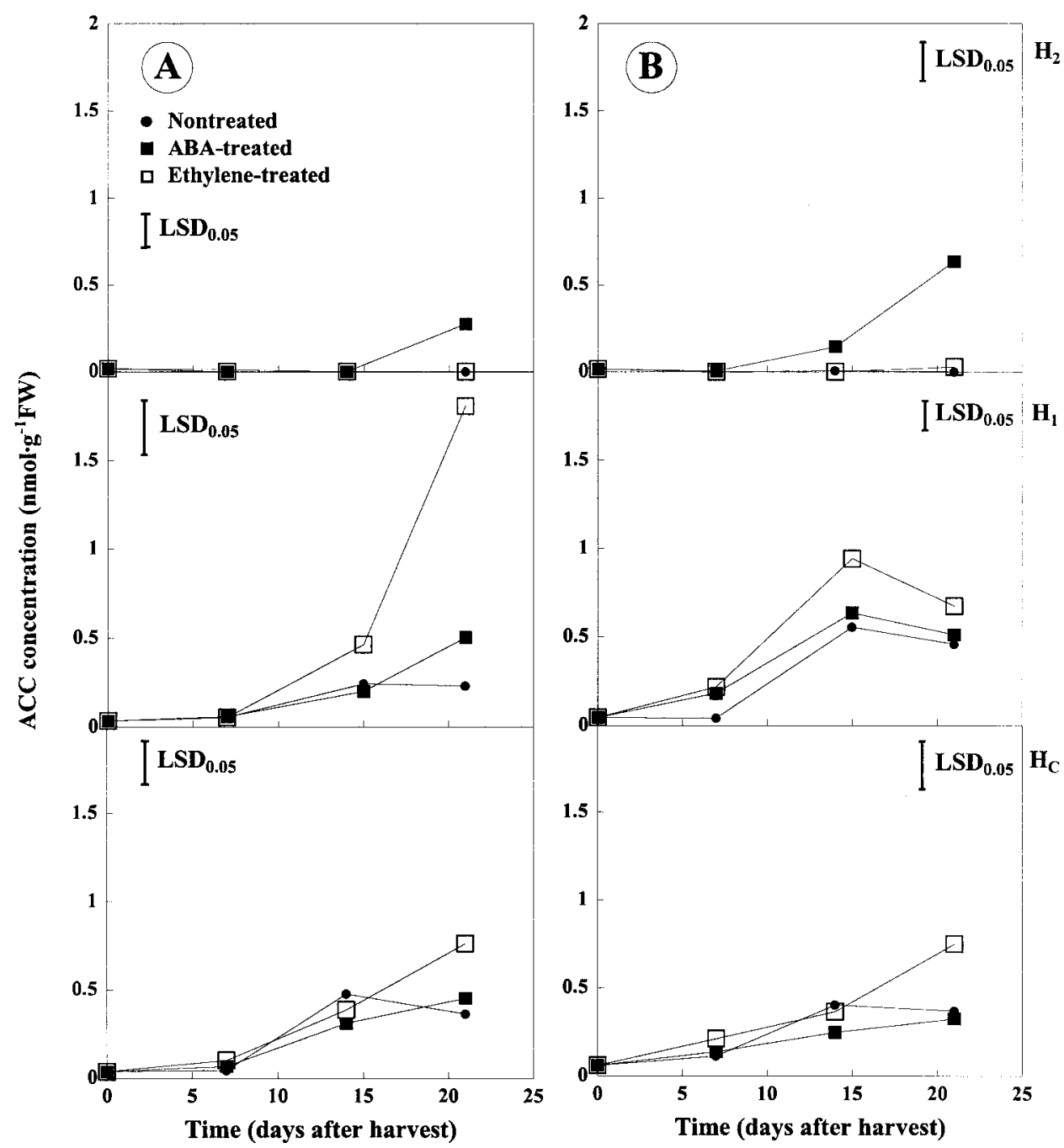

enhance the expression of ACC synthase, either directly or through a modification of ABA levels. Indeed, it has been reported (Pech et al., 1999) that exogenous ethylene stimulates ACS gene transcription in ACO-antisense melon (Cucumismelo L.) fruit, whereas ACS activity remains inhibited, thus suggesting this gene to be developmentally rather than ethylene regulated. This hypothesis could explain the remarkable correlation found between endogenous ABA and ACC levels in pulp of 'Granny Smith' apples during the preharvest period (Lara and Vendrell, 2000).

When preclimacteric $\mathrm{H}_{1}$ and $\mathrm{H}_{\mathrm{C}}$ fruit were pulsed with ethylene, the lag period referred to above was shortened but not abolished (Fig. 3). The concentration of ethylene required to trigger the climacteric in early preclimacteric fruit is considerably higher than that triggering it in late-season preclimacteric fruit (Starrett and Laties, 1991), indicating that sensitivity to ethylene increases with fruit maturity. However, the highest sensitivity to exogenous ethylene was observed in $\mathrm{H}_{1}$ fruit, harvested $\approx 1$ month before commercial harvest, as shown by endogenous ABA (Fig. 6), EFC (Fig. 4), ACC (Fig. 5), and MACC levels. It is also interesting that, at the $\mathrm{H}_{1}$ stage, ACS-related polypeptides could be detected in the pulp only in ethylene-

Fig. 5. ACC content in (A) peel and (B) pulp of 'Granny Smith' apples collected 2 months before commercial harvest $\left(\mathrm{H}_{2}\right), 1$ month before commercial harvest $\left(\mathrm{H}_{1}\right)$, and at commercial harvest $\left(\mathrm{H}_{\mathrm{C}}\right)$. Values represent means of four replications.

although ACS-related polypeptides were detected in the pulp 21 DAH (Fig. 1) and some accumulation of MACC was observed in the peel (data not presented). This suggests that the capability to synthesize large quantities of ethylene in response to ethylene, known as "autocatalytic regulation", may be lacking in very immature fruit. It has been postulated that during the ripening process both the expression of the gene and the development of activity of ACC oxidase precede those of ACC synthase (Yang and Dong, 1993). It has been reported that when preclimacteric apples are treated with ethylene for a short period ethylene production is not induced because there is no increased ACC synthesis, but the treatment causes a marked increase in ACC oxidase transcript (Dong et al., 1992). This is consistent with data herein, which showed no detectable accumulation of ACO protein either in peel or in pulp of $\mathrm{H}_{2}$ fruit in response to exogenous ethylene, whereas exogenous $\mathrm{ABA}$ induced accumulation of active ACO protein in both tissues. Thus, it might be hypothesized that the basal endogenous ethylene levels present during the preclimacteric are responsible for accumulation of ACO transcript, which would be translated in response to increased ABA levels. The de novo-synthesized ACO protein would cause an increase in endogenous ethylene levels, which in turn would treated fruit (Fig. 1), whereas treatment with ABA was unable to induce them. This is in accordance with the rest of results, which show ethylene biosynthesis in nontreated apples to increase with maturation stage. Thus, higher, close-to-saturating endogenous ethylene levels would explain the apparent lower sensitivity of $\mathrm{H}_{\mathrm{C}}$, compared with $\mathrm{H}_{1}$, apples to exogenous ethylene. These data, along with results indicating high tissue sensitivity to exogenous ABA in very immature $\left(\mathrm{H}_{2}\right)$ fruit, suggest that an increase in ABA levels may precede the increase in responsiveness to ethylene. How this may enhance ethylene responsiveness is currently unknown. Many of the actions of ABA involve modifications of gene expression at the transcriptional level, and multiple ABAresponsive genes have been isolated (Merlot and Giraudat, 1997).

In conclusion, this research demonstrated that treatment with exogenous ABA resulted in an increase of ACO protein abundance in preclimacteric immature 'Granny Smith' apples. This suggests ethylene production by preclimacteric apples may be limited in part by a reduced ability to convert ACC to ethylene, in addition to a restriction in ACS presence and/or activity. The authors acknowledge that the antibodies used in this study were unable to discriminate among the known ACO isoforms. It is possible that, in the early stages of development, exogenous ABA induced an ACO isoform gene which was not related to ripening. However, ACS-related polypeptides were detected in immunoprecipitation assays in response to $\mathrm{ABA}$ treatment, showing that $\mathrm{ABA}$ can induce ripening-related $\mathrm{ACC}$ synthase in immature 

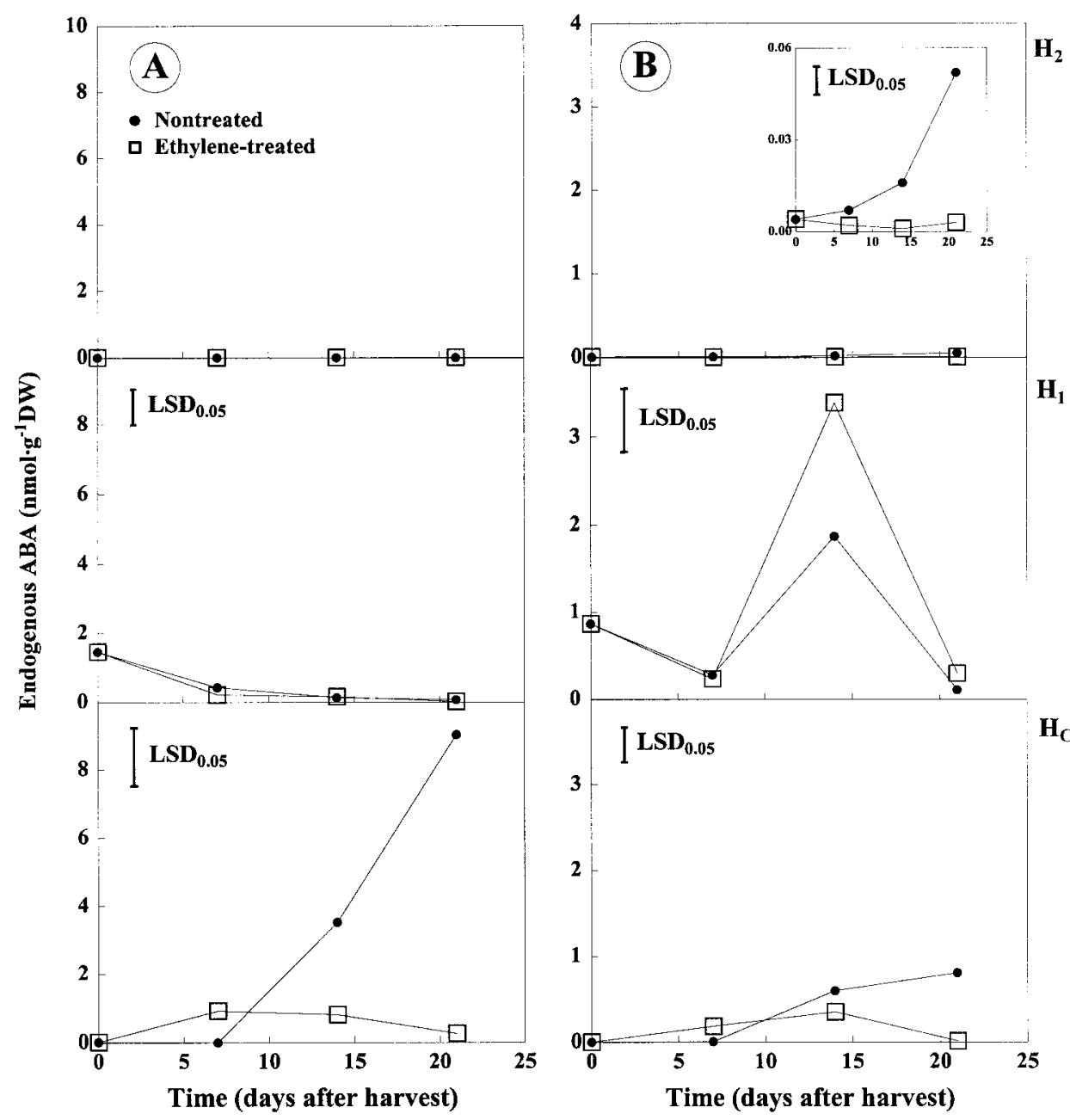

Burg, S.P. and E.A. Burg. 1962. Role of ethylene in fruit ripening. Plant Physiol. 37:179-189.

Callahan, A., P. Morgens, and E. Walton. 1989. Isolation and in vitro translation of RNAs from developing peach fruit. HortScience 24:356-358.

Carrasquer, A.M., I. Casals, and L. Alegre. 1990. Semi-automated method for the determination of ABA in crude plant extracts. J. Chromatog. 503:459-465.

Davies, K.M. and D. Grierson. 1989. Identification of cDNA clones for tomato ( $L y$ copersicon esculentum Mill.) mRNAs that accumulate during fruit ripening and leaf senescence in response to ethylene. Planta 179:73-80.

Domínguez, M. and M. Vendrell. 1994. Effect of ethylene treatment on ethylene production, EFE activity and ACC levels in peel and pulp of banana fruit. Postharvest Biol. Technol. 4:167-177.

Domínguez-Puigjaner,E., M. Vendrell, and M.D. Ludevid. 1992. Differential protein accumulation in banana fruit during ripening. Plant Physiol. 98:157-162.

Dong, J.G., J.C. Fernández-Maculet, and S.F. Yang. 1992. Purification and characterization of 1-aminocyclopropane-1-carboxylic acid oxidase from ripe apple fruit. Proc. Natl. Acad. Sci USA 89:9789-9793. Dong, J.G., W.K. Yip, and S.F. Yang. 1991. Monoclonal antibodies against apple 1-aminocyclopropane-1-carboxylate synthase. Plant Cell Physiol. 32:25-31.

Gómez Cadenas, A., F.R. Tadeo, M. Talón, and E. Primomillo. 1996. Leaf abscission induced by ethylene in water-stressed in-

Fig. 6. Endogenous ABA concentration in (A) peel and (B) pulp of 'Granny Smith' apples collected 2 months before commercial harvest $\left(\mathrm{H}_{2}\right), 1$ month before commercial harvest $\left(\mathrm{H}_{1}\right)$, and at commercial harvest $\left(\mathrm{H}_{\mathrm{C}}\right)$. Values represent means of three replications.

tissues. Our results suggest a role for ABA in the onset of the climacteric process of 'Granny Smith' apples, further supported by the changes in endogenous ABA concentrations throughout the experimental time, and by the negligible sensitivity of tissues to exogenous ethylene in $\mathrm{H}_{2}$ fruit.

\section{Literature Cited}

Ausubel, F.M., R. Brent, R.E. Kingston, D.D. Moore, J.G. Seidman, J.A. Smith, and K. Struhl. 1997. Current protocols in molecular biology. Wiley, New York.

Biggs, M.S., R.W. Harriman, and A.K. Handa. 1986. Changes in gene expression during tomato fruit ripening. Plant Physiol. 81:395-403.

Bozak, K.R., H. Yu, R. Sirevag, and R.E. Christoffersen. 1990. Sequence analysis of ripening-related cytochrome P-450 cDNAs from avocado fruit. Proc. Natl. Acad. Sci. USA 69:1408-1412.

Bradford, M.M. 1976. A rapid and sensitive method for the quantitation of microgram quantities of protein utilizing the principle of proteindye binding. Anal. Biochem. 72:248-254.

Brady, C.J. 1987. Fruit ripening. Annu. Rev. Plant Physiol. 38:155-178. Bufler, G. 1984. Ethylene enhanced ACC synthase activity in ripening apples. Plant Physiol. 75:192-195.

Bufler, G. 1986. Ethylene-promoted conversion of 1-aminocyclopropane1-carboxylic acid to ethylene in peel of apple at various stages of fruit development. Plant Physiol. 80:539-543. tact seedlings of 'Cleopatra' mandarin requires previous abscisic acid accumulation in roots. Plant Physiol. 112:401-408.

Hoffman, E.N. and S.F. Yang. 1984. Enhancement of wound-induced ethylene synthesis by ethylene treatment in preclimacteric cantaloupe. Plant Physiol. 60:317-322.

Hoffman, E.N., S.F. Yang, and T. McKean. 1982. Identification of MACC as a major conjugate of ACC, an ethylene precursor. Biochem. Biophys. Res. Comm. 104:765-770.

Inaba, A. and R. Nakamura. 1986. Effect of exogenous ethylene concentration and fruit temperature on the minimum treatment time necessary to induce ripening in banana fruit. J. Jpn. Soc. Hort. Sci. 55:348-354.

Inaba, A. and R. Nakamura. 1988. Numerical expression for estimating the minimum ethylene exposure time necessary to induce ripening in banana fruit. J. Amer. Soc. Hort. Sci. 113:561-564.

Knee, M. 1993. Pome fruits, p. 325-346. In: G.B. Seymour, J.E. Taylor, and G.A. Tucker (eds.). Biochemistry of fruit ripening. Chapman and Hall, London.

Kondo, S. and H. Gemma. 1993. Relationship between ABA content and maturation of the sweet cherry. J. Jpn. Soc. Hort. Sci. 62:63-68.

Kondo, S., J. Uthaibutra, and H. Gemma. 1991. Comparison of ACC, abscisic acid and anthocyanin content of some apple cultivars during fruit growth and maturation. J. Jpn. Soc. Hort. Sci. 60:505-511.

Lara, I. and M. Vendrell. 1998a. ACC oxidase activation by cold storage on 'Passe-Crassane' pears: Effect of calcium treatment. J. Sci. Food Agr. 76:421-426.

Lara, I. and M. Vendrell. 1998b. Relationships between ethylene, abscisic acid and quality during postharvest storage of 'Granny Smith' apples. Postharvest Biol. Technol. 13:11-18.

Lara, I. and M. Vendrell. 2000. Changes in abscisic acid levels, ethylene biosynthesis and protein patterns during fruit maturation of apples. J. 
Amer. Soc. Hort. Sci. 125:183-189.

Lay-Yee, M., D. DellaPenna, and G.S. Ross. 1990. Changes in mRNA and protein during ripening in apple fruit (Malus domestica Borkh. cv. Golden delicious). Plant Physiol. 94:850-853.

Lelièvre, J.M., A. Latché, B. Jones, M. Bouzayen, and J.C. Pech. 1997. Ethylene and fruit ripening. Physiol. Plant. 101:727-739.

Lincoln, J.E., S. Cordes, E. Read, and R.L. Fischer. 1987. Regulation of gene expression by ethylene during Lycopersicon esculentum (tomato) fruit development. Proc. Natl. Acad. Sci. USA 84:2793-2797.

Liu, Y., N.E. Hoffman, and S.F. Yang. 1985a. Promotion by ethylene of the capability o convert 1-aminocyclopropane-1-carboxylic acid to ethylene in preclimacteric tomato and cantaloupe fruits. Plant Physiol. 77:407-411.

Liu, Y., L.Y. Su, and S.F. Yang. 1985b. Ethylene promotes the capability to malonylate 1-aminocyclopropane-1-carboxylic acid and Daminoacids in preclimacteric tomato fruits. Plant Physiol. 77:891-895.

Lizada, M.C.C. and S.F. Yang. 1979. A simple and sensitive assay for ACC. Anal. Biochem. 100:140-145.

Lu, G., H. Liang, and Z. Lu. 1992. Metabolism of ribonucleic acid and protein in ripening apple fruits. J. Plant Physiol., 139:569-573.

Martínez Madrid, M.C., M. Serrano, F. Riquelme, and F. Romojaro. 1996. Polyamines, abscisic acid and ethylene production in tomato fruit. Phytochemistry 43:323-326.

McMurchie, E.J., W.B. Mc Glasson, and I.L. Eaks. 1972. Treatment of fruit with propylene gives information about the biogenesis of ethylene. Nature 237:235-236.

Merlot, S. and J. Giraudat. 1997. Genetic analysis of abscisic acid signal transduction. Plant Physiol. 114:751-757.

Moya-León, M.A. and P. John. 1995. ACC oxidase activity in pulp and peel of ripening bananas: In vivo and in vitro studies, p. 335-342. In: A. AitOubahou and M. El-Otmani (eds.). Postharvest physiology, pathology and technologies for horticultural commodities: Recent advances. Institut Agronomique et Vétérinaire Hassan II, Agadir, Morocco.

Nakatsuka, A., S. Murachi, H. Okunishi, S. Shiomi, R. Nakano, Y. Kubo, and A. Inaba. 1998. Differential expression and internal feedback regulation of 1-aminocyclopropane-1-carboxylate synthase, 1aminocyclopropane-1-carboxylate oxidase, and ethylene receptor genes in tomato fruit during development and ripening. Plant Physiol. 118:1295-1305.

Olson, D.C., J.A. White, R. Edelman, N. Harkins, and H. Kende. 1991. Differential expression of two genes for ACC synthase in tomato fruits. Proc. Natl. Acad.Sci. USA 8:5340-5344.

Pech, J.C., M. Guis, R. Botondi, R. Ayub, M. Bouzayen, J.M. Lelièvre, F. El Yahyaoui, and A. Latché. 1999. Ethylene-dependent and ethylene-independent pathways in a climacteric fruit, the melon, p. 105110. In: A.K. Kanellis, C. Chang, H. Klee, A.B. Bleecker, J.C. Pech, and D. Grierson (eds.). Biology and biotechnology of the plant hormone ethylene II. Kluwer Academic Publishers, Dordrecht, the Netherlands.

Peck, S.C., K. Pawlowski, and H. Kende. 1998. Asymetric responsiveness to ethylene mediates cell elongation in the apical hook of peas. Plant Cell 10:713-719.

Reid, M.S. 1985. Ethylene and abscission. HortScience 20:45-50.

Riov, J., E. Dagan, R. Goren, and S.F. Yang. 1990. Characterization of abscisic acid-induced ethylene production in citrus leaf and tomato fruit tissues. Plant Physiol. 92:48-53.

Smith, C.J.S., A. Slater, and D. Grierson. 1986. Rapid appearance of an mRNA correlated with ethylene synthesis encoding a protein of molecular weight 35,000. Planta 168:94-100.

Starrett, D.A. and G.G. Laties. 1991. Involvement of wound and climacteric ethylene in ripening avocado discs. Plant Physiol. 97:720-729.

Tari, I. and M. Nagy. 1996. Abscisic acid and ethrel abolish the inhibition of adventitious root formation of pacrobutrazol-treated bean primary leaf cuttings. Biol. Plant. 38:369-375.

Tucker, M.L. and G.G. Laties. 1984. Interrelationship of gene expression, polysome prevalence, and respiration during ripening of ethylene and/or cyanide-treated avocado fruit. Plant Physiol. 74:307-315.

Uthaibutra, J. and H. Gemma. 1991. Changes in abscisic acid content of peel and pulp of 'Jonagold' apples during pre- and post-harvest periods. J. Jpn. Soc. Hort. Sci. 60:443-448.

Vendrell, M. and C. Buesa. 1989. Relationship between abscisic acid content and ripening of apples. Acta Hort. 258:389-396.

Yang, S.F. and J.G. Dong. 1993. Recent progress in research of ethylene biosynthesis. Bot. Bul. Acad. Sin. 34:89-101. 